\title{
Evaluation of the microbial cell structure damages in alkaline pretreatment of waste activated sludge
}

\author{
Benyi Xiao ${ }^{a}$, Cao Liu ${ }^{b}$, Junxin Liu ${ }^{a}$, Xuesong Guo ${ }^{a, *}$ \\ ${ }^{a}$ Research Center for Eco-Environmental Sciences, Chinese Academy of Sciences, Beijing 100085, China \\ ${ }^{\mathrm{b}}$ Beijing Water Sciences Technology Institute, Beijing 100048, China
}

\section{H I G H L I G H T S}

- Damages of cell structures were evaluated during alkaline pretreatment of sludge.

- Most damages of cell structures occurred at the $\mathrm{pH}>10$ stage of $\mathrm{pH}$ increase.

- Damages of cell structures in the pH stabilization stage were low.

- Damage extent of cell structures should reach the cell membrane to release organics.

\section{A R T I C L E I N F O}

\section{Article history:}

Received 19 May 2015

Received in revised form 15 July 2015

Accepted 17 July 2015

Available online 23 July 2015

\section{Keywords:}

Alkaline pretreatment

Damage

Microbial cell structure

$\mathrm{pH}$

Waste activated sludge

\begin{abstract}
A B S T R A C T
This study investigated the damages of microbial cell structures, as well as the relationships between these damages and the release of cellular organic matter in the pretreatment of waste activated sludge (WAS) by using alkaline pretreatment as model. In the alkaline pretreatment of WAS, the most damage of bound extracellular polymeric substances (EPS), cell walls, cell membranes, and cell nuclei occurred at pH 11.5-12.0 (46.2\%), pH 11.0-11.5 (27.3\%), pH 9.0-10.0 (34.2\%), and pH 11.5-12.0 (44.4\%), respectively. The damage percentages of these cell structures in the $\mathrm{pH}$ stabilization stage were low because most of the damages occurred when the $\mathrm{pH}$ increased. The structural integrities of sludge microorganisms were all damaged in the $\mathrm{pH}$ increase stage. The damages of EPS, cell walls, and cell membranes were significantly correlated with the release of cellular organic matter, and these damages were necessary to release the cellular matter in WAS.
\end{abstract}

(ㄷ) 2015 Published by Elsevier Ltd.

\section{Introduction}

Waste activated sludge (WAS) is a main byproduct of the activated sludge process (an important biological wastewater treatment process), which requires further treatment and disposal (Wei et al., 2003; Guo et al., 2013). The sludge yield is usually $0.7-0.8 \mathrm{~kg} / \mathrm{kg}$ of five-day biochemical oxygen demand or $0.3-0.5 \mathrm{~kg} / \mathrm{kg}$ in terms of chemical oxygen demand (COD) in the activated sludge process (Grady et al., 2011). Due to the wide application of activated sludge process, WAS is mass-produced. For instance, the European Union produced over 10 million tons of dry WAS in 2005 (Paul and Debellefontaine, 2007). The USA generated about 8.2 million tons of dry WAS in 2010 (Wang et al., 2012 ), and over $3.48 \times 10^{7}$ tons of dewatered sludge (with $80 \%$ water content) was produced in China in 2011 (Feng et al.,

\footnotetext{
* Corresponding author. Tel./fax: +86 1062912465.

E-mail address: gxs0122@rcees.ac.cn (X. Guo).
}

2014). Moreover, the quantity of sludge has been increasing annually with the development of sewage treatment systems. The treatment and disposal of sludge, which may account for $25-65 \%$ of the total plant operation cost (Wei et al., 2003; Guo et al., 2013), has become a significant problem for many wastewater treatment plants.

In WAS, most organic matters are found in insoluble microbial cells, which are packed by various microbial cell structures, such as extracellular polymeric substances (EPS), cell walls, cell membranes, and cell nuclei (Weemaes and Verstraete, 1998), which exhibit low bioavailabilities. To release the organic matter and improve the bioavailabilities of WAS, various pretreatment processes have been widely used. These pretreatment methods include mechanical, thermal, chemical, and biological ones. Among them, alkaline pretreatment is a simple, widely used, and highly efficient chemical method (Li et al., 2012; Weemaes and Verstraete, 1998; Wonglertarak and Wichitsathian, 2014; Xiao et al., 2013; Zhang et al., 2010). In alkaline pretreatment, the 
amount of soluble organic matter of sludge increases with increasing $\mathrm{pH}$. Given that most organic matters released from the microbial cells of sludge are biodegradable (such as proteins, carbohydrates, and lipids), the bioavailability and treatment of sludge are improved (García Becerra et al., 2010). Most sludge pretreatments aim to solubilize biomass, disintegrate biological floc structure, and disrupt bacterial cells (Guo et al., 2013; Müller, 2001; Weemaes and Verstraete, 1998). In these pretreatments, the microbial cell structures of sludge are disrupted or damaged, resulting in solubilization of sludge and release of sludge organic matter. Several studies on sludge pretreatment have reported that such pretreatment can disrupt or damage some sludge microbial cell structures (Weemaes and Verstraete, 1998).

To date, most studies about sludge pretreatment have mainly focused on the release of sludge organic matter, which can be measured in terms of solubilization degree, disintegration degree, soluble COD (SCOD), soluble protein (SPro), and soluble carbohydrate (SCarb). Few studies have discussed the damages of various microbial cell structures, their degrees, and their relationships with the release of organic matter during sludge pretreatment. After pretreatment (including alkaline pretreatment), the sludge needs further treatment and disposal. Subsequent treatments of pretreated sludge include methane production with anaerobic digestion, hydrogen production with anaerobic fermentation, electricity production with microbial fuel cells, and volatile organic acid production with anaerobic fermentation. However, increased solubilization does not always improve the bioavailability, treatment, and disposal of sludge, and the released organic matter is not always utilized (Kim et al., 2013). These characteristic parameters cannot be used to accurately evaluate the economy of sludge pretreatments in improving the bioavailability of WAS and evaluating the damages of these cell structures. Additionally, few studies have discussed excessive sludge pretreatment and its economy because the previous parameters are insufficient to evaluate whether the intensity of pretreatment is necessary to improve the bioavailability of the sludge. Given that previously characterized parameters cannot be used to accurately evaluate the economics of sludge pretreatment, new parameters should be determined using novel insights obtained in other studies. Research about damages of sludge microbial structures may provide a new perspective because most of the sludge organic matters are cellular ones, and most of the soluble organic matters are released because of these damages in the sludge microbial structures.

Therefore, to provide a scientific basis for further research on the economy of sludge pretreatments in improving the bioavailability of WAS, the present study investigated the damages of sludge microbial structures, their characterizations and degrees, as well as the relationships between these damages and the release of sludge organic matter in the sludge pretreatment process by using alkaline pretreatment as model.

\section{Methods}

\subsection{WAS}

The WAS used in the tests was obtained from a municipal wastewater treatment plant in Beijing, China, which uses an activated sludge process and handles 400,000 tons of wastewater daily. The collected sludge samples were first screened and filtered using a 40-mesh sieve to remove large particles, washed thrice with deionized water, and stored at $4{ }^{\circ} \mathrm{C}$ until use. The $\mathrm{pH}$, total suspended solids (TSS), volatile suspended solids (VSS), SCOD, and total COD (TCOD) of WAS were $6.92 \pm 0.01,8.80 \pm 0.03$, $5.86 \pm 0.02,35 \pm 5$, and $5830 \pm 120 \mathrm{mg} / \mathrm{L}$, respectively.
Table 1

Sludge sampling points during alkaline pretreatment.

\begin{tabular}{llrl}
\hline No. & Sampling point & \multicolumn{1}{l}{ pH } & \multicolumn{1}{l}{ Stage } \\
\hline No. 1 & Raw sludge & $6.92 \pm 0.01$ & pH increase stage \\
No. 2 & pH 8.00 after stable 5 min & $8.00 \pm 0.01$ & \\
No. 3 & pH 9.00 after stable 5 min & $9.00 \pm 0.01$ & \\
No. 4 & pH 10.00 after stable 5 min & $10.00 \pm 0.01$ & \\
No. 5 & pH 11.00 after stable 5 min & $11.00 \pm 0.01$ & \\
No. 6 & pH 11.50 after stable 5 min & $11.50 \pm 0.01$ & \\
No. 7 & pH 12.00 after stable 5 min & $12.00 \pm 0.01$ & \\
No. 8 & pH 12.50 after stable 5 min & $12.50 \pm 0.01$ & \\
No. 9 & pH 12.50 after 1 h & $12.46 \pm 0.01$ & pH stabilization stage \\
No. 10 & pH 12.50 after 2 h & $12.45 \pm 0.01$ & \\
No. 11 & pH 12.50 after 6 h & $12.43 \pm 0.01$ & \\
No. 12 & pH 12.50 after 24 h & $12.42 \pm 0.01$ & \\
\hline
\end{tabular}

\subsection{Alkaline pretreatment of WAS}

The alkaline pretreatment of sludge can be divided into two stages: the $\mathrm{pH}$ increase stage and the $\mathrm{pH}$ stabilization stage after the sludge $\mathrm{pH}$ reaches a set value. In the experiment, the alkaline pretreatment $\mathrm{pH}$ was set to 12.50 , and the sludge $\mathrm{pH}$ was gradually adjusted to $8.00,9.00,10.00,11.00,11.50,12.00$, and 12.50 by adding $6 \mathrm{M} \mathrm{NaOH} \mathrm{(AR)} \mathrm{with} \mathrm{stirring} \mathrm{at} 100 \mathrm{rpm}$ in the $\mathrm{pH}$ increase stage at room temperature $\left(20-25^{\circ} \mathrm{C}\right)$. Each $\mathrm{pH}$ of sludge was kept stable for $5 \mathrm{~min}$ to ensure treatment efficiency. The sludge was sampled at each $\mathrm{pH}$ to study the changes of the sludge characteristics in the $\mathrm{pH}$ increase stage. After the sludge $\mathrm{pH}$ reached 12.5 , the $\mathrm{pH}$ stabilization stage started, and the pretreated sludge was then stirred $(300 \mathrm{rpm})$ at room temperature $\left(20-25^{\circ} \mathrm{C}\right)$ for $24 \mathrm{~h}$. To study the changes of the sludge characteristics in the $\mathrm{pH}$ stabilization stage, the sludge was sampled at 1, 2, 6, and $24 \mathrm{~h}$. The sludge sampling points during alkaline pretreatment are summarized in Table 1.

\subsection{Analysis}

The sludge $\mathrm{pH}$ was measured using a pH meter (Sartorius PB-10, Germany). The TCOD and SCOD of sludge were determined using a HACH COD detector (DR2800, USA). SCOD was measured after the sludge was filtered using a $0.45 \mu \mathrm{m}$ membrane. The VSS and TSS of sludge were analyzed via standard methods (APHA, 1998). The pretreated sludge (including raw sludge) was washed thrice with deionized water before the bound EPS were extracted via formaldehyde-NaOH methods (Liu and Fang, 2002). The SPro of sludge and bound EPS (EPS-Pro) were determined using the Lowry method (Lowry et al., 1951) with bovine serum albumin as the standard. The SCarb of sludge and bound EPS (EPS-Carb) were determined using the phenol-sulfuric acid method with glucose as the standard (Dubois et al., 1956).

Table 2

Damage percentages of microbial cell structures in the alkaline pretreatment of WAS. Sample Damage percentage of

\begin{tabular}{lllll} 
& $\begin{array}{l}\text { Bound EPS } \\
(\%)\end{array}$ & $\begin{array}{l}\text { Cell walls } \\
(\%)\end{array}$ & $\begin{array}{l}\text { Cell membranes } \\
(\%)\end{array}$ & $\begin{array}{l}\text { Cell nuclei } \\
(\%)\end{array}$ \\
\hline No. 1 & 0 & 0 & 0 & 0 \\
No. 2 & 6.4 & 0 & 3.0 & 0.7 \\
No. 3 & 18.4 & 0.7 & 6.2 & 1.5 \\
No. 4 & 23.0 & 1.7 & 40.4 & 3.9 \\
No. 5 & 37.8 & 12.5 & 50.5 & 20.4 \\
No. 6 & 43.2 & 39.8 & 60.5 & 45.5 \\
No. 7 & 89.4 & 62.8 & 65.0 & 89.9 \\
No. 8 & 94.2 & 86.0 & 79.1 & 91.4 \\
No. 9 & 102.8 & 93.1 & 86.1 & 93.0 \\
No. 10 & 103.1 & 97.3 & 95.2 & 94.8 \\
No. 11 & 103.7 & 99.2 & 99.5 & 97.9 \\
No. 12 & 100 & 100 & 100 & 100
\end{tabular}


The average sizes of the sludge samples were determined using a laser particle size analyzer (Malvern Mastersizer 2000, UK). Sludge dewaterability was investigated via the capillary suction time (CST) method (Standard Methods 2710G) by using a CST meter (304M, Triton Electronics, Essex, England) (Murugesan et al., 2014). For the Fourier transform infrared spectroscopy (FTIR) analyses of the soluble organic matter, the filtrate of $0.45 \mu \mathrm{m}$ membrane was freeze-dried, and the dry matter mixed with dried $\mathrm{KBr}$ was analyzed with an FTIR spectrometer (TENSOR 27 , BRUKER Germany) at a frequency range of $4000-400 \mathrm{~cm}^{-1}$. The damages of microbial cell walls were evaluated in terms of the $\mathrm{N}$-acetylglucosamine content (one of cell wall hydrolysates) (Guo et al., 2014), which was detected via the Morgan-Elson colorimetric method with glucosamine as the standard (Morgan and Elson, 1934). The damages of microbial cell membranes were evaluated via flow cytometry (FCM; FACSCalibur, BD Pharmingen, Heidelberg, Germany) (Prorot et al., 2008; Guo et al., 2014). The damages of microbial cell nuclei were evaluated in terms of the DNA content, which was measured via the diphenylamine colorimetric method by using fish sperm DNA and sodium salt as the standard (Sun et al., 1999). The sludge samples were analyzed via scanning electron microscopy (SEM; S-3000N, Hitachi Co., Japan) following the sludge sample preparation method as previously described (Xiao et al., 2013).

\subsection{Statistical approach for correction analysis}

Statistical analysis was performed to identify the quantitative relationships of the cell structures damages and the released organic matter; moreover, a representative approach of univariate linear correlations was applied (Ou et al., 2014) using IBM SPSS Statistics 16.0 software (SPSS Inc., USA). The Pearson's product momentum correlation coefficient was referred to as the $r$ value and used for linear estimation. Pearson's $r$ can range from -1 to 1. An $r$ of -1 indicates a perfect negative linear relationship between variables, an $r$ of 0 indicates no linear relationship between variables, and an $r$ of 1 indicates a perfect positive linear relationship between variables.

\section{Results and discussion}

\subsection{Release of cellular organic matter during alkaline pretreatment}

During alkaline pretreatment, some cellular organic matters were released into water at different $\mathrm{pH}$ values, which resulted in the increase of soluble matter. SCOD, SPro, and SCarb were detected for each sludge sample during alkaline pretreatment, and the results are summarized in Fig. 1.

The SCOD of sludge only increased from 15 to $78 \mathrm{mg} / \mathrm{L}$ when the $\mathrm{pH}$ was lower than 10.00 in the $\mathrm{pH}$ increase stage. The SCOD then rapidly increased with increasing $\mathrm{pH}$, and the greatest amount of SCOD released was $682 \mathrm{mg} / \mathrm{L}$ (from 996 to $1648 \mathrm{mg} / \mathrm{L}$ ) at $\mathrm{pH}$ 12.00-12.50 (Fig. 1). In the $\mathrm{pH}$ stabilization stage, the SCOD of the sludge continuously increased with alkaline pretreatment time. The changes in the solubilization degrees were similar to those of SCOD because the same sludge was used in the test. Proteins and carbohydrates were the main components of SCOD for the alkaline-pretreated sludge. The changes in SPro and SCarb were similar to those in SCOD, in which they increased with increasing $\mathrm{pH}$ in the $\mathrm{pH}$ increase stage and with pretreatment time in the pH stabilization stage (Fig. 1). By contrast, the increases in SPro and SCarb were low when the $\mathrm{pH}$ was lower than 10.00. The contents of SPro and SCarb in the SCOD of various sludge samples were obtained by calculation (Fig. 1). The SPro content changed in $45.4-80.6 \%$, and that at $\mathrm{pH} 10.00$ was the highest. The
SCarb content changed in 5.4-25.2\%, with the lowest change at $\mathrm{pH} 12.00$ in the $\mathrm{pH}$ increase stage, but remained relatively stable (5.4-7.8\%) in the $\mathrm{pH}$ stabilization stage. The ratios of SPro and SCarb changed from 1.8 to 13.6 , with the highest ratio at $\mathrm{pH}$ 12.00 in the $\mathrm{pH}$ increase stage, and then changed from 10.0 to 11.8 , with the highest ratio at $2 \mathrm{~h}$ in the $\mathrm{pH}$ stabilization stage. These results showed that the alkaline pretreatment of sludge can be divided into two stages in the $\mathrm{pH}$ increase stage: the release of soluble organic matter was low in the first stage $(\mathrm{pH}<10.00)$ and then increased in the second stage $(\mathrm{pH}>10.00)$.

FTIR spectroscopy was used to characterize soluble organic matter in various alkaline-pretreated sludge samples in a frequency range of $4000-400 \mathrm{~cm}^{-1}$ wavenumbers (data were not shown). In the FTIR spectra of sludge samples, there were broad and strong FTIR spectra bands ranging from 3300 to $3500 \mathrm{~cm}^{-1}$ for all samples, which might be attributed to $\mathrm{OH}$ or $\mathrm{NH}$ stretching vibrations. Meanwhile, there were five bands around 2941, 1660, 1550,1058 , and $574 \mathrm{~cm}^{-1}$ in the FTIR spectra of all samples, which were corresponded to $\mathrm{C}-\mathrm{H}$ stretching vibrations, antisymmetric $\mathrm{CO}_{2}$ stretching vibrations, $\mathrm{NH}_{3}^{+}$stretching vibrations in amino acids, $\mathrm{C}=\mathrm{O}$ stretching vibrations in carbohydrates, and $\mathrm{C}-\mathrm{O}$ stretching vibrations in carbohydrates, respectively (Larkin, 2011). The above results showed that proteins (including amino acids) and carbohydrates were present in these alkaline-pretreated sludge samples. Compared with the FTIR spectra of soluble organic matter for sludge samples at different $\mathrm{pH}$ values, the peak positions around $550,1050,1550$, and $3300-3500 \mathrm{~cm}^{-1}$ for the sludge samples shifted at different $\mathrm{pH}$ values in the $\mathrm{pH}$ increase stage. The band shift suggested that the structures of the released organic matter at different $\mathrm{pH}$ values were different. However, the infrared spectra of all sludge samples in the $\mathrm{pH}$ stabilization stage were similar, which suggested that the characterization results of organic matter released in this stage were also similar. The aforementioned results showed that the released organic matter in the alkaline pretreatment of sludge was affected by the pretreatment $\mathrm{pH}$ in the $\mathrm{pH}$ increase stage but not by the pretreatment time in the $\mathrm{pH}$ stabilization stage.

The experimental results showed that the organic matters released in the alkaline pretreatment of sludge were different in terms of content and structure when the pretreatment $\mathrm{pH}$ and time were varied. These results suggested that the damages of microbial cell structures may vary at different $\mathrm{pH}$ values during the alkaline pretreatment of WAS.

\subsection{Damages of microbial cell structures}

In WAS, the cellular matter was wrapped with various microbial cell structures, including EPS, cell walls, cell membranes, and cell nuclei. These microbial cell structures were damaged during the alkaline pretreatment of sludge, and cellular matters were released and converted into soluble ones. Tests were conducted to evaluate the damages of these microbial cell structures.

\subsubsection{Damages of bound EPS}

EPS, an important microbial cell structure of activated sludge, serves an important function in biological wastewater treatment (Wilén et al., 2003; Sheng et al., 2010). Given that EPS are extracellular compounds located outside microbial cells, these compounds are damaged first in the alkaline pretreatment of sludge. EPS include proteins, carbohydrates, humic substances, lipids, and nucleic acids, and the first two are the main types (Liu and Fang, 2002). An extremely high $\mathrm{pH}$ during alkaline pretreatment causes proteins to lose their natural shapes and leads to lipid saponification and RNA hydrolysis (Neyens et al., 2004), resulting in damages of bound EPS. In the present study, the bound EPS content was 


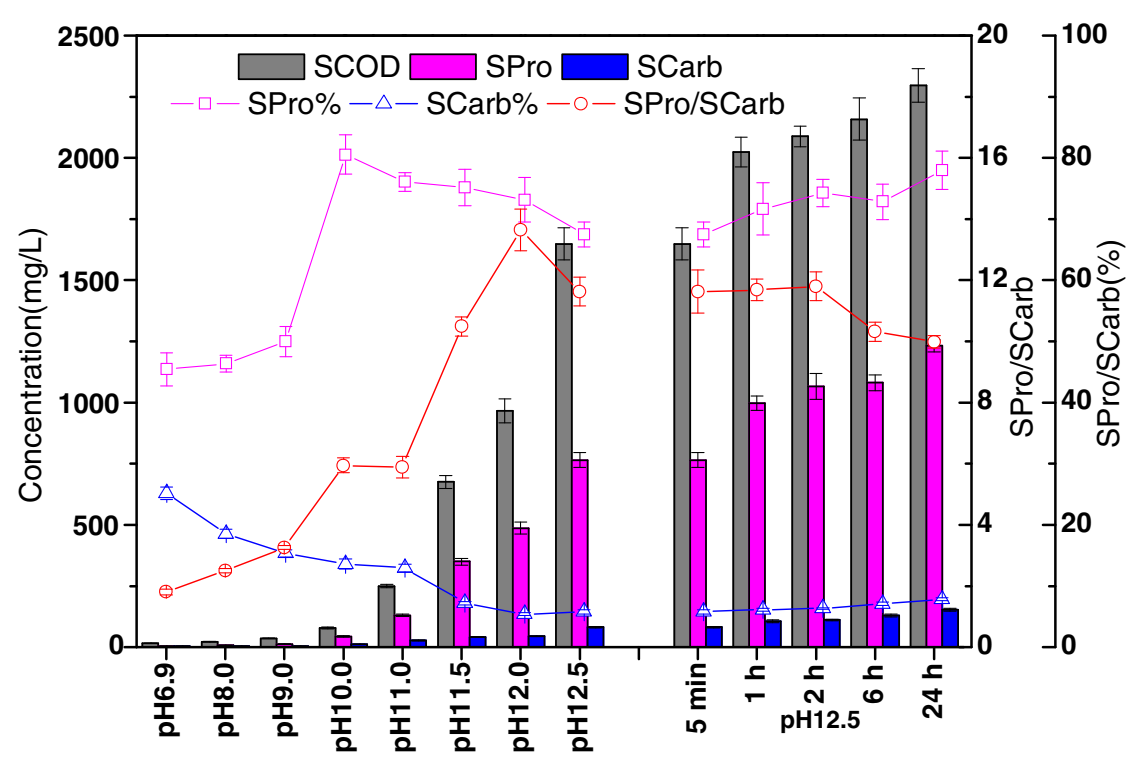

Fig. 1. Changes of organic matters in alkaline pretreated sludge.

determined on the basis of the protein and carbohydrate contents (Fig. 2).

The contents of proteins and carbohydrates in bound EPS decreased from 122.3 and 84.4 to 23.5 and $27.5 \mathrm{mg} / \mathrm{L}$ with increasing pretreatment $\mathrm{pH}$ in the $\mathrm{pH}$ increase stage, respectively. The maximum decrease occurred at $\mathrm{pH} 11.50-12.00$ (50.6 mg/L protein and $25.7 \mathrm{mg} / \mathrm{L}$ carbohydrate). In the $\mathrm{pH}$ stabilization stage (at $\mathrm{pH}$ 12.50 ), the contents of proteins and carbohydrates in bound EPS were relatively stable at $14.2-23.5$ and $21.3-27.5 \mathrm{mg} / \mathrm{L}$, respectively, which suggested that no further damages of sludge bound EPS occurred in the $\mathrm{pH}$ stabilization stage. The ratios of proteins and carbohydrates in the bound EPS ranged from 0.81 to 1.59 in the $\mathrm{pH}$ increase stage and were relatively stable from 0.66 to 0.85 (Fig. 2). The above results suggested that alkaline pretreatment can damage the bound EPS in terms of content and composition, and various $\mathrm{pH}$ values resulted in different levels of damages.
The bound EPS plays an important role in maintaining the sludge floc structure and functions, and the damages of bound EPS would affect the structure of the sludge floc and result in changes in floc structures (Sobeck and Higgins, 2002; Sheng and Yu, 2006). The alterations in sludge floc structures were presented in terms of the changes in average particle size, specific surface area, and dewaterability (CST) (Fig. 3). The average particle size of the sludge during alkaline pretreatment decreased from 101.2 to $82.4 \mu \mathrm{m}$ in the entire process, whereas the specific surface area of the sludge increased from 0.114 to $0.130 \mathrm{~m}^{2} / \mathrm{g}$. Both the decrease rate of average particle sizes and the increase rate of specific surface areas differed in the two stages of alkaline pretreatment. In the stage with $\mathrm{pH} 7.00-12.00$, the CST of the sludge slightly increased from 8.5 to $56.3 \mathrm{~s}$. Following this stage $(\mathrm{pH}$ 12.00-12.50 after $2 \mathrm{~h}$ ), the CST of the sludge rapidly increased from 56.3 to $408.1 \mathrm{~s}$ then slowly increased. At the end of the $\mathrm{pH}$

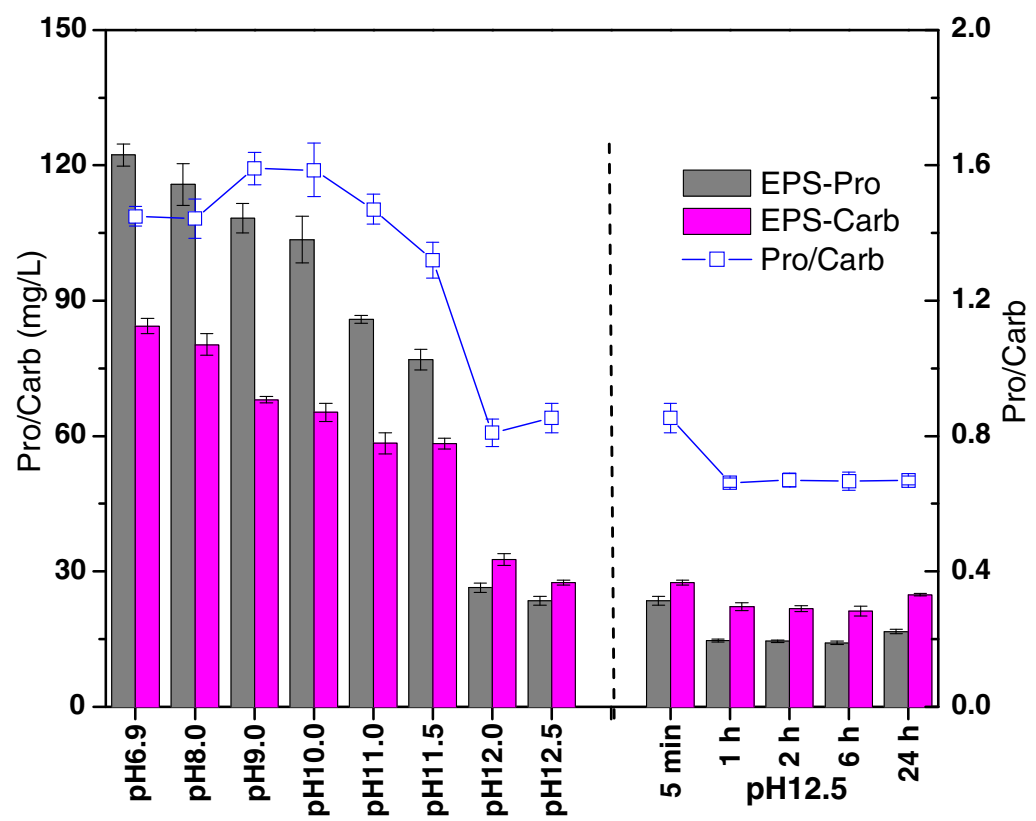

Fig. 2. Changes of protein and carbohydrate in sludge bound EPS. 


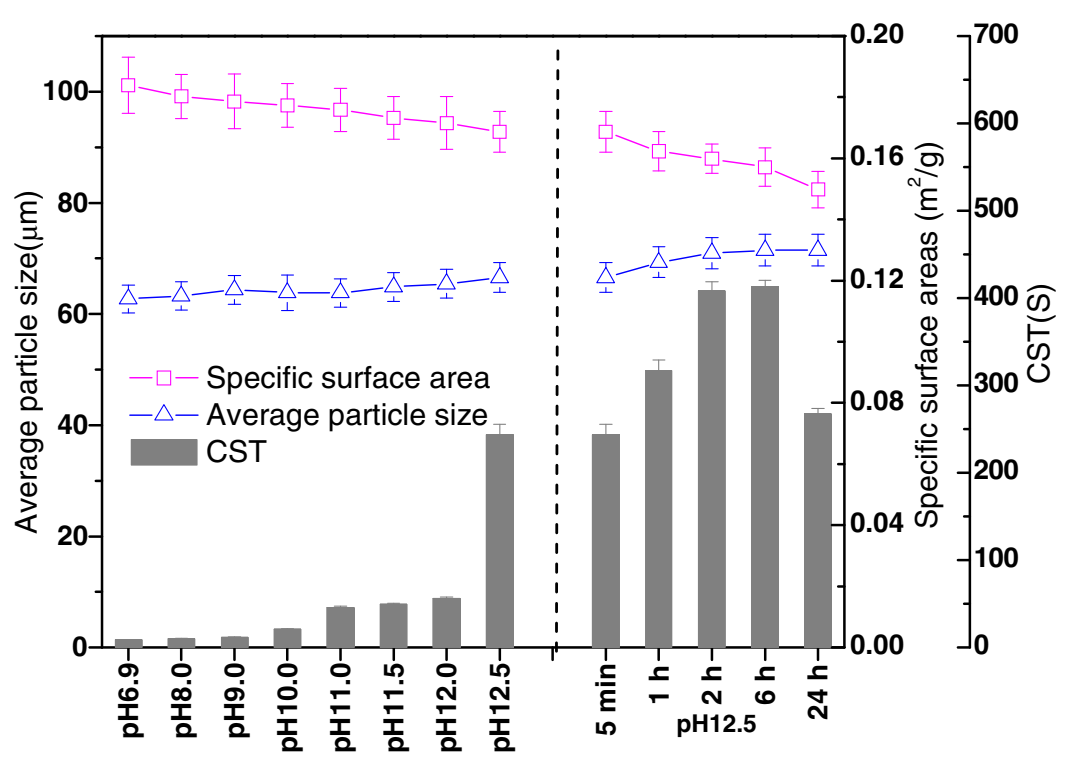

Fig. 3. Changes of sludge floc structure during alkaline pretreatment.

stabilization stage ( $\mathrm{pH} 12.50$ after $6 \mathrm{~h}$ to $\mathrm{pH} 12.50$ after $24 \mathrm{~h}$ ), the CST of the sludge decreased. The alterations in average particle sizes, specific surface areas, and CST suggested that the sludge floc structures changed, which indicated that the function of bound EPS also changed. The results showed that alkaline pretreatment can damage the function of sludge EPS.

\subsubsection{Damages of cell walls, cell membranes, and cell nuclei}

After the bound EPS was damaged, the cells were exposed to an environment with extreme $\mathrm{pH}$. The cell walls, cell membranes, and cell nuclei of sludge microbial cells were further damaged because of hydroxyl anions during alkaline pretreatment.

Peptidoglycan, an important component of microbial cell walls, is hydrolyzed once the cell walls are damaged, and $\mathrm{N}$-acetylglucosamine and $\mathrm{N}$-acetylmuramic acid are subsequently released (Guo et al., 2014). To study the damages of the cell walls, the contents of soluble $\mathrm{N}$-acetylglucosamine in the sludge were measured (Fig. 4). Minimal increases in the amount of soluble $\mathrm{N}$-acetylglucosamine (from 0.002 to $0.004 \mathrm{mg} / \mathrm{L}$ ) were observed at a pretreatment $\mathrm{pH}$ value lower than 10.00 in the $\mathrm{pH}$ increase stage. In the present study, the amount of soluble $\mathrm{N}$-acetylglucosamine in pretreated sludge rapidly increased from 0.004 to $0.122 \mathrm{mg} / \mathrm{L}$ when the pretreatment $\mathrm{pH}$ was increased in the range of 10.00-12.50. In the $\mathrm{pH}$ stabilization stage, the amount of soluble $\mathrm{N}$-acetylglucosamine of sludge slightly increased from 0.122 to $0.142 \mathrm{mg} / \mathrm{L}$, which may be ascribed to the presence of some cell wall damages in this stage.

During the alkaline pretreatment of sludge, the cell membranes were exposed and damaged after the cell walls had been damaged. The damaging and damaged cell membranes of the sludge were characterized using two fluorochromes (propidium iodide and FITC Annexin V) via FCM measurements (Fig. 4). In pH 7.00-9.00 of the $\mathrm{pH}$ increase stage, the ratio of cell membrane integrity slightly decreased from $87.0 \%$ to $84.7 \%$, and that of the damaging and damaged cell membranes only increased from $4.8 \%$ to $5.7 \%$ and from $8.2 \%$ to $9.5 \%$, respectively, which suggested that the damage extent of the cell membranes was low in this stage. When the pretreatment $\mathrm{pH}$ was increased to 10.00 , the ratio of cell membrane integrity decreased to $80.4 \%$, and that of the damaging and damaged cell membranes significantly increased to $7.5 \%$ and $12.2 \%$, respectively. The ratio of cell membrane integrity started to rapidly decrease with increasing $\mathrm{pH}$ and reached $12.5 \%$ at $\mathrm{pH}$
12.50. In this stage, the ratio of the damaging cell membranes decreased, whereas that of the damaged cell membranes rapidly increased and reached $86.3 \%$ at $\mathrm{pH} 12.50$. In the $\mathrm{pH}$ stabilization stage, the ratio of the damaging cell membranes decreased, but that of the damaged cell membranes only slightly increased with pretreatment time and then reached $95.9 \%$ at the end of the experiment. These results showed that the damages of cell membranes progressed up to the final steps of the $\mathrm{pH}$ increase stage $(\mathrm{pH}>9.00)$ and $\mathrm{pH}$ stabilization stage. The results were reasonable because the disruption of the sludge cell membranes started when the alkaline hydrolysis pH was higher than 11.00 (Bi et al., 2014).

After the cell walls and cell membranes were damaged, the cell nuclei were also damaged, and DNA was released and converted into soluble matter (Celis, 2005). The release of DNA is shown in Fig. 4. In the first part ( $\mathrm{pH} 7.00-10.00)$ of the $\mathrm{pH}$ increase stage, the increase in the amount of soluble DNA was low, and its content only slightly increased from 6.3 to $10.5 \mathrm{mg} / \mathrm{L}$, which showed that the damages of the cell nuclei were minimal in this stage. When the pretreatment $\mathrm{pH}$ increased from 10.00 to 12.00 , the content of soluble DNA rapidly increased from 10.5 to $103.6 \mathrm{mg} / \mathrm{L}$. In the $\mathrm{pH}$ stabilization stage, the soluble DNA content only increased by approximately $11.0 \mathrm{mg} / \mathrm{L}$ (from 103.6 to $114.6 \mathrm{mg} / \mathrm{L}$ ), probably because most of the cell nuclei had been damaged (Liu and Fang, 2002; Sheng et al., 2010). The above results showed that the damages of cell nuclei mostly occurred at $\mathrm{pH} 10.00-12.00$ in the $\mathrm{pH}$ increase stage.

The damage percentages of microbial cell structures in the alkaline pretreatment of WAS can be obtained using the start sample (No. 1 with $\mathrm{pH}$ 6.92) as $0 \%$ and the end sample (No. 12 with $\mathrm{pH}$ 12.42 ) as $100 \%$ (Table 2). The most severe damages of bound EPS, cell walls, cell membranes, and cell nuclei occurred at pH 11.5012.00 (46.2\%), pH 11.00-11.50 (27.3\%), pH 9.00-10.00 (34.2\%), and $\mathrm{pH} 11.50-12.00(44.4 \%)$, respectively. Most of these microbial cell structures were damaged in the $\mathrm{pH}$ increase stage, and the damage percentages were $94.2 \%$ (bound EPS), $86.0 \%$ (cell walls), 79.1\% (cell membranes), and 91.4 (cell nuclei).

\subsubsection{Integrity of sludge microorganisms}

The integrity of sludge microorganisms during the alkaline pretreatment of sludge was observed via SEM (data were not shown). The integrity of sludge microorganisms was damaged once the microbial cell structures were damaged. In SEM of raw sludge, 


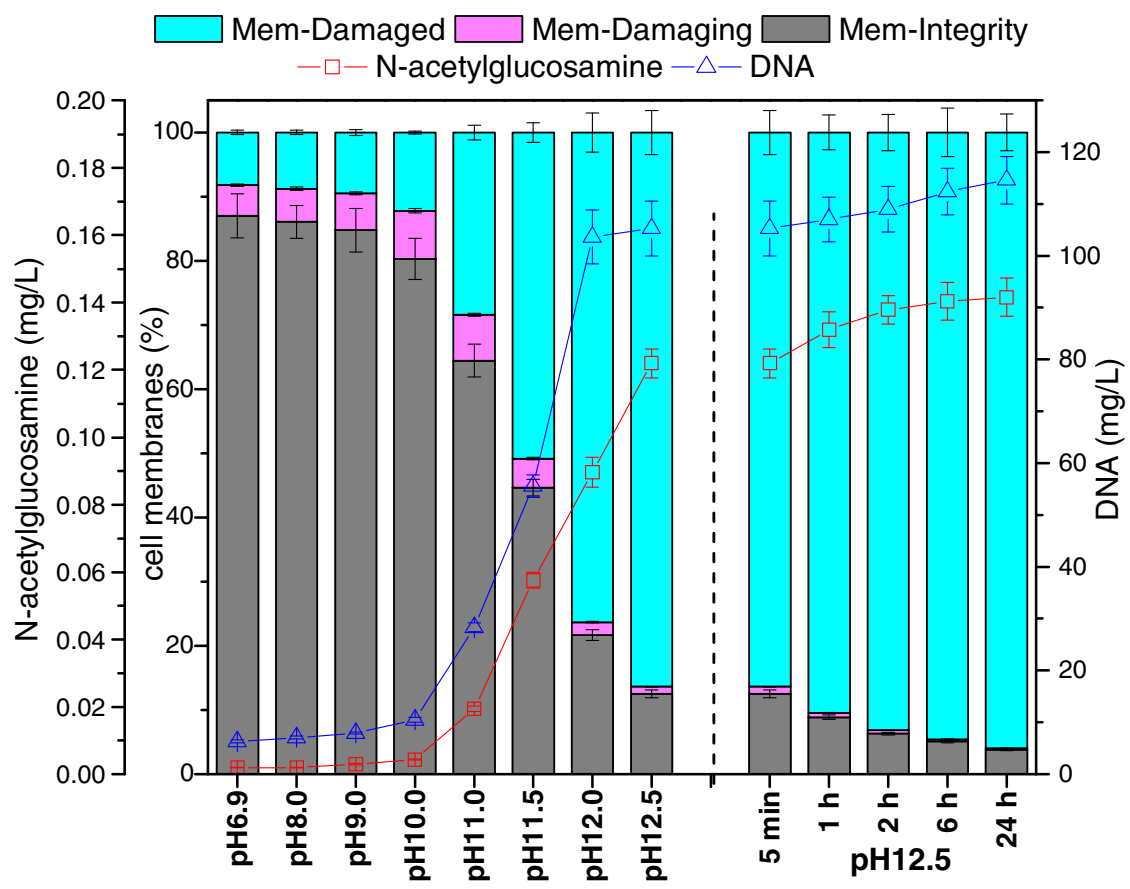

Fig. 4. Changes of soluble $\mathrm{N}$-acetylglucosamine and DNA and damage of cell membranes during alkaline pretreatment of sludge.

Table 3

Pearson's correlations between damages of cell structures and released organic matter.

\begin{tabular}{|c|c|c|c|c|c|c|}
\hline \multirow[t]{2}{*}{ Parameter } & \multicolumn{3}{|l|}{ Damage } & \multirow[t]{2}{*}{ SCOD } & \multirow[t]{2}{*}{ SCarb } & \multirow[t]{2}{*}{ SPro } \\
\hline & Cell walls & Cell membranes & Cell nuclei & & & \\
\hline Damage to EPS $^{1}$ & $-0.977^{* * 2}$ & $-0.962^{* *}$ & $-0.687^{* 3}$ & $-0.952^{* *}$ & $-0.906^{* *}$ & $-0.944^{* *}$ \\
\hline Damage to cell walls & & $0.983^{* *}$ & $0.684^{*}$ & $0.989^{* *}$ & $0.951^{* *}$ & $0.979^{* *}$ \\
\hline Damage to cell membranes & & & $0.570^{*}$ & $0.976^{* *}$ & $0.965^{* *}$ & $0.970^{* *}$ \\
\hline Damage to cell nuclei & & & & $0.650^{*}$ & 0.402 & $0.639^{*}$ \\
\hline
\end{tabular}

${ }^{1}$ EPS $=$ protein and carbohydrate in EPS

$2{ }^{* *}$ Significant correlation, $p<0.01,2$-tailed.

$3{ }^{*}$ General correlation, $p<0.05$, 2-tailed.

the sludge microorganisms were intact with smooth surfaces. When the pretreated $\mathrm{pH}$ increased to 9.00, their surfaces were rough because the EPS was partly damaged. When the pretreated $\mathrm{pH}$ was higher than 10.0 , the integrity of sludge microorganisms deteriorated and the unintact sludge microorganism appeared in the SEM of sludge samples. Meanwhile the integrity ratio decreased with increasing $\mathrm{pH}$. In the SEM of sludge samples in the $\mathrm{pH}$ stabilization stage, almost no intact sludge microorganisms were found. Moreover, the microorganisms in the sludge were all destroyed after alkaline pretreatment at $\mathrm{pH} 12.50$ for $24 \mathrm{~h}$ (specifically at the end of the $\mathrm{pH}$ stabilization stage). The above results showed that the integrities of sludge microorganisms were all damaged in the $\mathrm{pH}$ increase stage. Additionally, the damage extent of the cell wall and the integrity of the microorganisms were consistent with each other (Fig. 4) because the integrity of microorganisms was lost once the cell walls were damaged (Celis, 2005).

\subsection{Relationships of cell structure damages and released organic matter}

The Pearson's correlations between the damages of various cell structures and released organic matter are summarized in Table 3. The damages of EPS, cell walls, and cell membranes were significantly correlated with the contents of SCOD, SPro, and SCarb, respectively, which were also correlated with the damages of the cell nuclei. The correlation between the damages of EPS and the other parameters was negative, and the other correlations were positive. The $r$ value between cell wall damage and SCOD release was the highest (0.989), followed by the $r$ value between the damage of cell walls and membranes (0.983). The damages of cell nuclei were positively correlated with the contents of SCOD and SPro. The results suggested that the damages of EPS, cell walls, and cell membranes were significantly correlated with the release of cellular matter, and they occurred almost simultaneously. The coexistence of many microbial cells in the sludge resulted in their simultaneous damages during the alkaline pretreatment, although the individual cell structures were gradually damaged. The relationship between the cell structure damages and released organic matter showed that the extent of damage should reach the cell membrane to release the cellular organic matter of sludge.

\section{Conclusions}

The damages of EPS occurred at $\mathrm{pH} 7.00-12.50$, and rapid damages were observed at $\mathrm{pH} 11.50-12.00$. The most damages of the cell walls and cell membranes occurred at $\mathrm{pH} 10.00-12.50$ and $\mathrm{pH}$ 9.00-12.50, respectively. The highest damage percentage of the cell nuclei occurred at $\mathrm{pH} 10.00-12.00$. The damages of EPS, cell walls, and cell membranes were significantly correlated with each other, whereas those of cell nuclei were only correlated with 
the release of cellular organic matter. Hence, the cell membranes should be damaged to release the cellular organic matter of sludge.

\section{Acknowledgements}

The authors are grateful to the Major Science and Technology Program for Water Pollution Control and Treatment (2012ZX07203-001 and 2014ZX07101-012), the National Natural Science Foundation of China (No. 51378492) and Chinese Academy of Sciences 135 project (YSW2013B06).

\section{References}

APHA, 1998. Standard Methods for the Examination of Water and Wastewater, 20th ed. American Public Health Association, Washington DC, USA.

Bi, W., Li, Y.Y., Hu, Y.Y., 2014. Recovery of phosphorus and nitrogen from alkaline hydrolysis supernatant of excess sludge by magnesium ammonium. Bioresour. Technol. 166, 1-8.

Celis, J.E., 2005. Cell Biology: A Laboratory Handbook, vol. 1. Elsevier Inc.

Dubois, M., Gilles, K.A., Hamilton, J.K., Rebers, P.A., Smith, F., 1956. Colorimetric method for determination of sugars and related substances. Anal. Chem. 28 , $350-356$.

Feng, X.C., Guo, W.Q., Yang, S.S., Zheng, H.S., Du, J.S., Wu, Q.L., Ren, N.Q., 2014. Possible causes of excess sludge reduction adding metabolic uncoupler $3,3^{\prime}, 4^{\prime}, 5$-tetrachlorosalicylanilide (TCS), in sequence batch reactors. Bioresour. Technol. 173, 96-103.

García Becerra, F.Y., Acosta, E.J., Allen, D.G., 2010. Alkaline extraction of wastewater activated sludge biosolids. Bioresour. Technol. 101, 6983-6991.

Grady Jr, C.P.L., Daigger, G.T., Love, N.F., Filipe, C.D.M., 2011. Biology of Wastewater Treatment, third ed. IWA Publishing, UK.

Guo, W.Q., Yang, S.S., Xiang, W.S., Wang, X.J., Ren, N.Q., 2013. Minimization of excess sludge production by in-situ activated sludge treatment processes - a comprehensive review. Biotechnol. Adv. 31 (8), 1386-1396.

Guo, X.S., Liu, J.X., Xiao, B.Y., 2014. Evaluation of the damage of cell wall and cell membrane for various extracellular polymeric substance extractions of activated sludge. J. Biotechnol. 188, 130-135.

Kim, D.H., Cho, S.K., Lee, M.K., Kim, M.S., 2013. Increased solubilization of excess sludge does not always result in enhanced anaerobic digestion efficiency. Bioresour. Technol. 143, 660-664.

Larkin, P., 2011. Infrared and Raman Spectroscopy: Principles and Spectral Interpretation. Elsevier Inc.

Li, H., Li, C.C., Liu, W.J., Zou, S.X., 2012. Optimized alkaline pretreatment of sludge before anaerobic digestion. Bioresour. Technol. 123, 189-194.

Liu, H., Fang, H.H.P., 2002. Extraction of extracellular polymeric substances (EPS) of sludges. J. Biotechnol. 95, 249-256.

Lowry, O.H., Rosebrough, N.J., Farr, A.L., Randall, R.J., 1951. Protein measurement with the Folin phenol reagent. J. Biol. Chem. 1993, 265-275.
Morgan, W.T.J., Elson, L.A., 1934. A colorimetric method for the determination of Nacetylglucosamine and N-acetylchrondrosamine. Biochem. J. 28, 988-995.

Müller, J.A., 2001. Prospects and problems of sludge pre-treatment processes. Water Sci. Technol. 44 (10), 121-128.

Murugesan, K., Ravindran, B., Selvam, A., Kurade, M.B., Yu, S.M., Wong, J.W., 2014 Enhanced dewaterability of anaerobically digested sewage sludge using Acidithiobacillus ferrooxidans culture as sludge conditioner. Bioresour. Technol. 169, 374-379.

Neyens, E., Baeyens, J., Dewil, R., De heyder, B., 2004. Advanced sludge treatment affects extracellular polymeric substances to improve activated sludge dewatering. J. Hazard. Mater. 106 (2-3), 83-92.

Ou, H.S., Wei, C.H., Mo, C.H., Wu, H.Z., Ren, Y., Feng, C.H., 2014. Novel insights into anoxic/aerobic(1)/aerobic(2) biological fluidized-bed system for coke wastewater treatment by fluorescence excitation-emission matrix spectra coupled with parallel factor analysis. Chemosphere 113, 158-164.

Paul, E., Debellefontaine, H., 2007. Reduction of excess sludge produced by biological treatment processes: effect of ozonation on biomass and on sludge. Ozone Sci. Eng. 29, 415-427.

Prorot, A., Eskicioglu, C., Droste, R., Dagot, C., Leprat, P., 2008. Assessment of physiological state of microorganisms in activated sludge with flow cytometry: application for monitoring sludge production minimization. J. Ind. Microbiol. Biotechnol. 35 (11), 1261-1268.

Sheng, G.P., Yu, H.Q., 2006. Chemical-equilibrium-based model for describing the strength of sludge: taking hydrogen-producing sludge as an example. Environ. Sci. Technol. 40, 1280-1285.

Sheng G.P. Yu, H.Q. Li, XY 2010. Extracellular polymeric substances (EPS) of microbial aggregates in biological wastewater treatment systems: a review. Biotechnol. Adv. 28, 882-894.

Sobeck, D.C., Higgins, M.J., 2002. Examination of three theories for mechanisms of cation-induced bioflocculation. Water Res. 36, 527-538.

Sun, Y., Clinkenbeard, K.D., Clarke, C., Cudd, L., Highlander, S.K., Dabo, S.M., 1999. Pasteurella haemolytica leukotoxin induced apoptosis of bovine lymphocytes involves DNA fragmentation. Vet. Microbiol. 65, 153-166.

Wang, Z.W., Mei, X.J., Ma, J.X., Wu, Z.C., 2012. Recent advances in microbial fuel cells integrated with sludge treatment. Chem. Eng. Technol. 35 (10), 1733-1743.

Weemaes, M.P.J., Verstraete, W.H., 1998. Evaluation of current wet sludge disintegration techniques. J. Chem. Technol. Biot. 73, 83-92.

Wei, Y., Van Houten, R.T., Borger, A.R., Eikelboom, D.H., Fan, Y., 2003. Minimization of excess sludge production for biological wastewater treatment. Water Res. 37, $4453-4467$.

Wilén, B.M., Jin, B., Lant, P., 2003. The influence of key chemical constituents in activated sludge on surface and flocculation properties. Water Res. 37, $2127-$ 2139.

Wonglertarak, W., Wichitsathian, B., 2014. Alkaline pretreatment of waste activated sludge in anaerobic digestion. J. Clean Energy Technol. 2 (2), 118-121.

Xiao, B.Y., Yang, F., Liu, J.X., 2013. Evaluation of electricity production from alkaline pretreated sludge using two-chamber microbial fuel cell. J. Hazard. Mater. 254255, 57-63.

Zhang, D., Chen, Y.G., Zhao, Y.X., Zhu, X.Y., 2010. New sludge pretreatment methods to improve methane production in waste activated sludge digestion. Environ. Sci. Technol. 44, 4802-4808. 